\title{
An ultrastructural study of oogenesis in the polychaete Nephtys hombergi Savigny
}

\author{
M. G. Bentley \\ Gatty Marine Laboratory, University of St. Andrews; St. Andrews, Fife KY16 8LB, \\ Scotland, U.K.
}

\begin{abstract}
The polychaete Nephtys hombergi has an annual cycle of reproduction. Ovaries were fixed for electron microscopy during the gametogenic phase from September to March, and during the breeding and post-breeding period. Oogenesis takes place entirely within the ovary, the integrity of which is maintained by a network of simple follicle cells. Previtellogenic oocytes have close contacts with the peri-vasal cells which surround the genital blood capillaries. These contacts are lost as the oocytes enter vitellogenesis. The vitellogenic oocytes have a cytology typical of oocytes which are thought to undergo autosynthetic production of protein yolk. Biochemical studies would be required to establish whether heterosynthesis of yolk also occurs. As the oocytes proceed through vitellogenesis, cortical material is laid down near the periphery of the oocyte and a microvillous surface is developed. When the microvillous surface is complete the oocytes, by then hormone independent, are ovulated from the ovary and are ready to be spawned.
\end{abstract}

\section{INTRODUCTION}

The ovaries of Nephtys hombergi are paired structures which are present in each of the post-pharyngeal segments (Olive, 1978). Development of oocytes within the ovaries commences in September and continues throughout the winter months (Olive, 1978). The oocytes are retained within the ovaries until vitellogenesis is complete. They are then released from the ovaries (Olive \& Bentley, 1980) and float freely in the coelomic fluid until they are spawned in the spring (Bentley et al., 1984). The ovaries develop around blind-ending blood capillaries at the base of the parapodia. A light microscopical study of the ovaries and oocyte development was carried out by Olive (1978) and this showed that the ovary consists of a network of fine peritoneal cells, which make up a simple follicle cell system. The term follicle cell is used to describe these cells because of the very close relationship they have to the developing oocytes and because of the essential role they play in allowing normal oogenesis to proceed (Olive \& Bentley, 1980). The follicle cells surround the oocyte throughout their development and the integrity of the ovary is maintained by contact areas between the follicle cells and developing oocytes.

Vitellogenic oocytes of $N$. hombergi require the support of a gonadotrophic hormone for normal oogenesis to proceed (Olive \& Bentley, 1980). This hormone maintains follicle cell contacts thus preventing premature ovulation and resorption of oocytes which have not completed the formation of a microvillous surface. Once vitellogenic oocytes have completed the microvillous surface, contacts between oocytes and follicle cells are lost and the oocytes are released from the ovaries prior to spawning. 
Oogenesis in $N$. hombergi begins with the production of primary oocytes around the capillaries of the genital blood vessels. Usually, the ovary at this time, contains a number of oocytes well into oogenesis and at almost full size, as a result of incomplete spawning of the previous year's cohort of oocytes in the spring (Olive et al., 1981a; Olive et al., $1981 \mathrm{~b}$; Olive et al., 1985). Whilst most unspawned oocytes are resorbed, it may be that some of these oocytes will remain in the ovary throughout the next phase of gametogenesis and be spawned in the following April or May. This phenomenon of incomplete spawning seems to be a common feature of $N$. hombergi in the River Tyne estuary but is variable in extent from year to year (Olive et al., 1985).

\section{MATERIALS AND METHODS}

Specimens of Nephtys hombergi were collected, by digging in sand at low water of spring tides, at a site in the River Tyne estuary, North-east England known locally as the "Black Middens". Animals were anaesthetized in $0.07 \% \mathrm{MS} 222$ (Sandoz) in sea water. The ovaries were removed by making a mid-dorsal incision through the body wall and lifting the ovaries out using watchmakers forceps. Excised ovaries were immersed immediately in $2.5 \%$ glutaraldehyde in $0.2 \mathrm{M}$ phosphate buffer (Millonig, 1961) containing $0.14 \mathrm{M} \mathrm{NaCl}$ at $\mathrm{pH} 7.4$ and fixed for $1 \mathrm{~h}$ at room temperature. The ovaries were then rinsed in phosphate buffer containing $0.14 \mathrm{M} \mathrm{NaCl}$ for $10 \mathrm{~min}$. and post-fixed in $2 \%$ osmium tetroxide in $0.2 \mathrm{M}$ phosphate buffer at $\mathrm{pH} 7.4$ containing $1.25 \% \mathrm{NaHCO}_{3}$ for $1 \mathrm{~h}$ (Fischer, 1975). The tissue was then rinsed in several changes of tap water and dehydrated through an alcohol series and propylene oxide before being embedded in araldite. Sections were cut using an LKB Ultratome, mounted on copper grids and stained with Reynold's lead citrate and uranyl acetate. Stained sections were examined on either an EM6B or Kratos Cora electron microscope.

\section{RESULTS}

\section{Protogonia and pre-meiotic stages}

In this study no special attempt was made to examine germ cell proliferation and stages of meiotic prophase. Light microscopical examination however reveals the presence of protogonia in interphase on the genital blood vessels (Olive, 1978). Mitotic figures have been observed in acetic orcein squash preparations (Bentley, unpublished) and stages of meiotic prophase are commonly seen in the ovary in September. Oocytes remain arrested at this stage until after spawning and germinal vesicle breakdown occurs following liberation of oocytes into the surrounding sea water.

\section{Previtellogenic oocytes}

Previtellogenic oocytes can be seen in the ovary of Nephtys hombergi from September to April but are present in largest numbers at the beginning of the period of active gametogenesis in September. They are found in the ovary in areas near the blind-ending blood capillaries with which they may develop close associations (Fig. 1).

Previtellogenic oocytes have a large, prominent nucleus which has a diameter of 
$10-20 \mu \mathrm{m}$. The nucleus is a fairly empty looking structure which may have a nucleolus situated near the nuclear envelope. The nucleolus is a homogenous electron-dense structure. In some previtellogenic oocytes the nucleolus appears absent and the nucleus contains dispersed chromatin lumps, some of which are concentrated close to the nuclear envelope (Fig. 2). There is evidence for transfer of chromatin-like material across the nuclear envelope to the cytoplasm (Fig. 3). The cytoplasm of previtellogenic oocytes is relatively featureless. Mitochondria are the most abundant cell inclusion and these are ovoid in shape. The mitochondria may be localised in areas near the nuclear membrane, where they are found in association with accumulations of chromatin-like material. They also occur further away from the nucleus and near the cell surface. Previtellogenic oocytes also contain small amounts of endoplasmic reticulum which often have connections with the nuclear envelope. A few lipid droplets may also be seen in oocytes at this stage. Golgi bodies are virtually absent in early previtellogenic oocytes.

The surface of previtellogenic oocytes is characterised by the presence of a smooth oolemma and an absence of microvilli. The oocytes are completely surrounded by follicle cells (Fig. 4) and there is close contact between the plasma membrane of the follicle cells and the oolemma. No specialised junctions or cytoplasmic continuity occurs between adjacent cells as has been reported in some polychaete species (Fischer, 1975) and which occurs between early spermatocytes in Nephtys (Bentley, unpublished observations). It is at this stage however that the oocytes have their most intimate contact with other cells. Around the blood capillaries in the centre of the ovaries, peri-vasal cells are enveloped by the cytoplasm of the oocytes (Fig. 5) and these peri-vasal cells may pass through "holes" in the oocyte cytoplasm. Similar arrangements have been reported in some other polychaetes Phragmatopoma lapidosa (Eckelbarger, 1979), Kefersteinia cirrata (Olive \& Pillai, 1983) and Diplocirrus glaucus (see Olive, 1983) but these contacts are rather more complex than those described here in Nephtys. Figure 6 shows a diagrammatic representation of the ovarian structure in Nephtys and shows the changes which occur in the oocyte surface and the changing relationship between the,oocyte, follicle cells and perivasal cells as oogenesis progresses.

\section{Vitellogenic oocytes}

Oocytes enter vitellogenesis when they attain a diameter of about $50 \mu \mathrm{m}$ and have a nuclear diameter of about $20 \mu \mathrm{m}$. This phase of development continues within the ovary until the oocytes have completed vitellogenesis and have a diameter of 180-200 $\mu \mathrm{m}$ with a nuclear diameter of about $40 \mu \mathrm{m}$. The nucleus during vitellogenesis remains electronlucent with a granular appearance and the nucleolus either becomes bipartite and is electron-dense with a less densely staining medulla, or it may become fragmented.

The vitellogenic phase is characterised by the appearance of active golgi complexes which produce eletron-dense material (Fig. 7) and which may assume a spherical configuration during later vitellogenesis (Fig. 8). The yolk granules are up to $2.5 \mu \mathrm{m}$ in diameter and accumulate throughout the cytoplasm during this growth phase. The yolk granules are heterogenous in appearance, having irregularly shaped densely staining areas (Fig. 9) and they may also have a regular striated pattern over part of them (Fig. 10). Lipid droplets also accumulate in the cytoplasm during vitellogenesis. Rough endoplasmic reticulum is present in the cytoplasm and has mitochondria in close proximity to its 


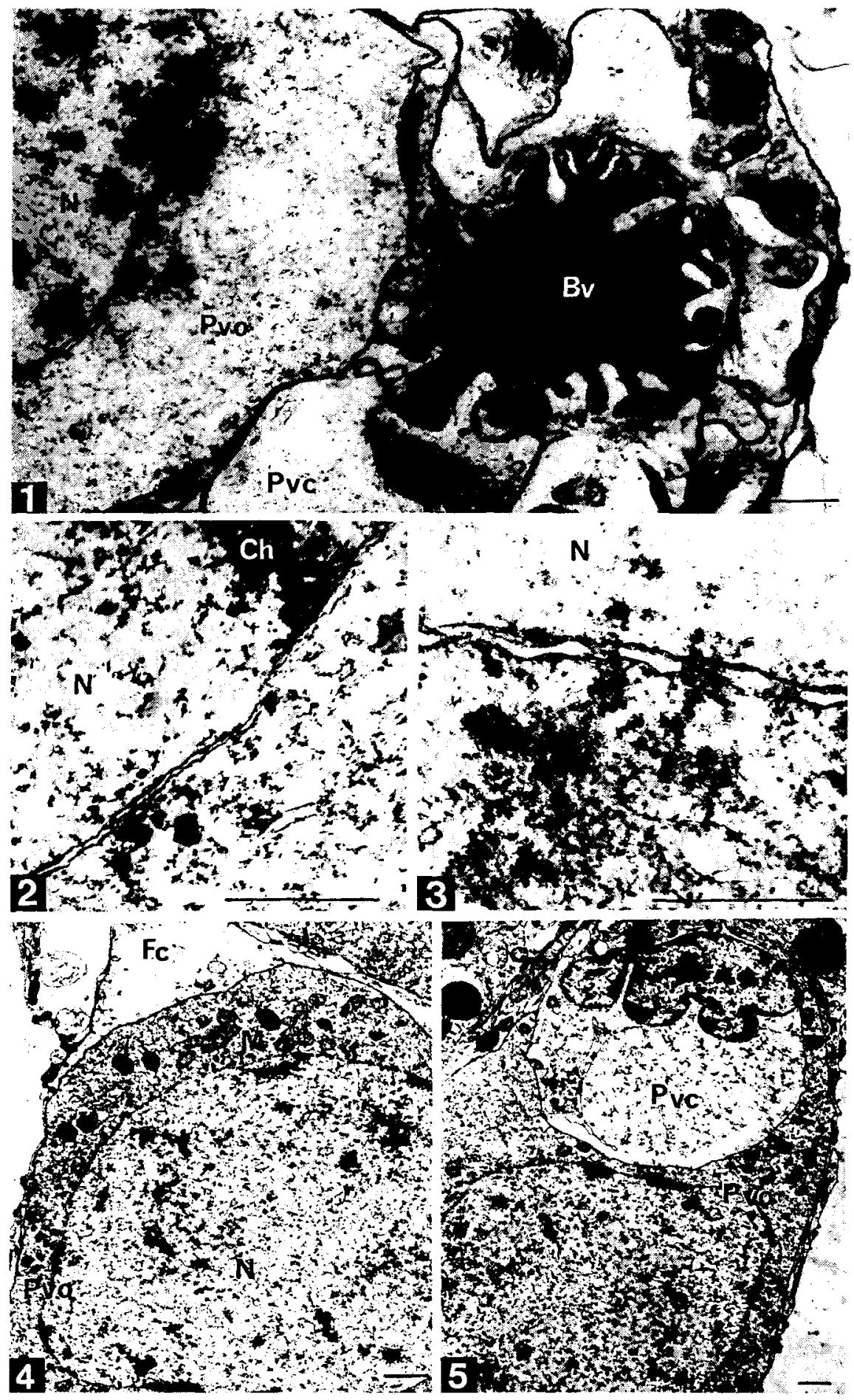


cisternae. Connections between rough endoplasmic reticulum and annulate lamellae can be seen close to the nuclear envelope (Fig. 11).

Early during the vitellogenic phase, cortical vesicles begin to be deposited near the oocyte surface. These are about $1 \mu \mathrm{m}$ in diameter and are electron-lucent except for fibrillar inclusions in some (Fig. 12). A few electron-dense, membrane-bound cortical granules which may be spherical or cigar-shaped and are also about $1 \mu \mathrm{m}$ in diameter are present near the surface of the oocyte at this stage (Fig. 12). As vitellogenesis proceeds, large bodies of annulate lamellae (Fig. 13) appear in the cytoplasm and these give rise to clear vesicles which contain small granular inclusions (Fig. 14). These vesicles may represent expanded cisternae of rough endoplasmic reticulum.

In mature oocytes the cytoplasm is full of protein yolk granules and lipid droplets. The mitochondria have developed "hollow" vesicles (Fig. 15), and golgi complexes are mostly absent, although a few non-active profiles remain. The cortical region of the oocyte has large numbers of cortical vesicles and cortical granules which contain rodshaped inclusions.

\section{Development of the egg envelope and microvilli}

Previtellogenic oocytes, as described above, have a smooth oolemma which is invested in a covering of follicle cells. The plasma membrane of the follicle cell is closely applied to the oolemma. There are no specialised junctions between the oolemma and follicle cell membrane although close junctions between adjacent follice cells do occur (Fig. 16). At these points there is a thickening of the plasma membranes of adjacent follicle cells. Similar desmosomes have been reported between adjacent follicle cells in Phragmatopoma lapidosa (Eckelbarger, 1979).

Early during vitellogenesis, the egg envelope or chorion and microvilli begin to develop. This occurs in small patches on the surface of the oocyte. In these areas, the close contact of the oolemma and follicle cell membrane is lost. At other points on the oocyte surface, there remain large areas where close contacts are retained. These folliclecell contact areas become smaller with the progressive development of the microvillous surface of the oocyte. This is illustrated diagrammatically in Figure 6. Finally, as the

Fig. 1. A previtellogenic oocyte in close association with the peri-vasal cells which surround a blood capillary in an ovary. Scale bar $=1 \mu \mathrm{m}(\mathrm{Bv}=$ blood vessel, $\mathrm{N}=$ nucleus, $\mathrm{Pvc}=$ peri-vasal cell, Pvo $=$ previtellogenic oocyte)

Fig, 2. Chromatin situated in close proximity to the nuclear envelope. Scale bar $=1 \mu \mathrm{m}(\mathrm{Ch}=$ chromatin, $\mathrm{N}=$ nucleus)

Fig. 3. Transfer of chromatin-like material across the nuclear envelope of a previtellogenic oocyte. Scale bar $=0.5 \mu \mathrm{m}(\mathrm{N}=$ nucleus $)$

Fig. 4. Part of a previtellogenic oocyte and its associated follicle cell covering. Follicle cells completely cover the surface of previtellogenic oocytes. Scale bar $=1 \mu \mathrm{m}$ (Fc $=$ follicle cell, $\mathrm{M}=$ mitochondria, $\mathrm{N}=$ nucleus, $\mathrm{Pvo}=$ previtellogenic oocyte)

Fig. 5. Previtellogenic oocytes may almost completely surround the perivasal cell. Scale bar $=1 \mu \mathrm{m}$ $($ Pvc $=$ peri-vasal cell, Pvo $=$ previtellogenic oocyte $)$ 


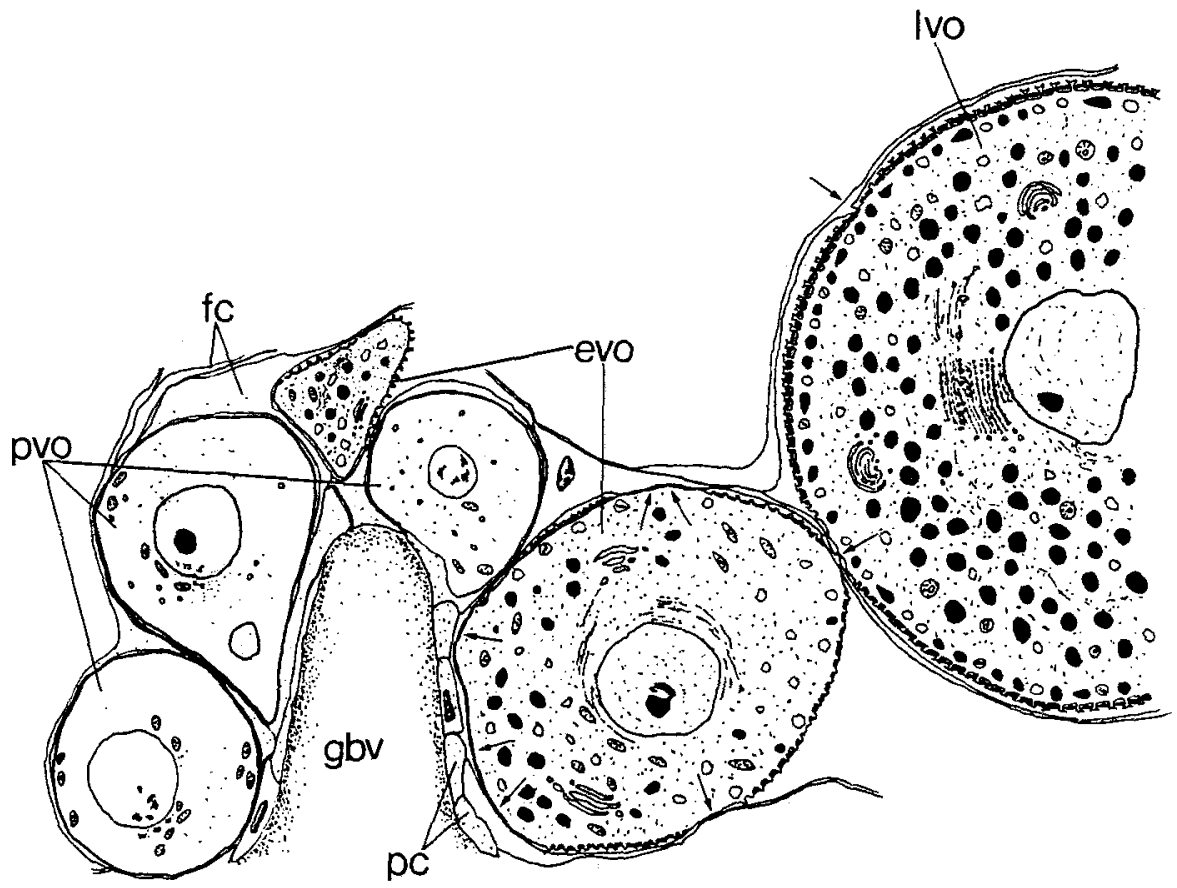

6

Fig. 6. A diagrammatic representation of ovarian development in Nephtys hombergi. The previtellogenic oocytes are found close to the genital blood vessel and are completely surrounded by, and in close contact with the follicle cells. As the oocytes progress through vitellogenesis they are found further away from the blood vessel, and follicle cell contacts become reduced until they remain as simple stalks (arrowed) (evo = early vitellogenic oocyte, $\mathrm{gbv}=$ genital blood vessel, lvo = late vitellogenic oocyte, $\mathrm{pc}=$ perivasal cell, pvo = previtellogenic oocyte)

Fig. 7. Active golgi complexes in the cytoplasm of a vitellogenic oocyte. Electron-dense material is being produced by the golgi, and large numbers of mitochondria are associated with the active golgi profiles. Scale bar $=1 \mu \mathrm{m}(\mathrm{G}=$ golgi complex, $M=$ mitochondria $)$

Fig. 8. A spherical golgi profile and associated electron-dense material. Scale bar $=1 \mu \mathrm{m}(\mathrm{G}=$ golgi complex)

Fig. 9. A general view of the cytoplasm of a vitellogenic oocyte showing a number of yolk granules which have irregular dense staining patches in them. Scale bar $=1 \mu \mathrm{m}(\mathrm{G}=$ golgi complex, Yg $=$ yolk granule)

Fig. 10. A yolk granule showing characteristic striations within the body of the granule. Scale bar $=$ $0.5 \mu \mathrm{m}(\mathrm{Yg}=$ yolk granule)

Fig. 11. Rough endoplasmic reticulum which may be associated with annulate lamellae near the nuclear membrane. Scale bar $=0.5 \mu \mathrm{m}(\mathrm{M}=$ mitochondrion, $\mathrm{Rer}=$ rough endoplasmic reticulum) 

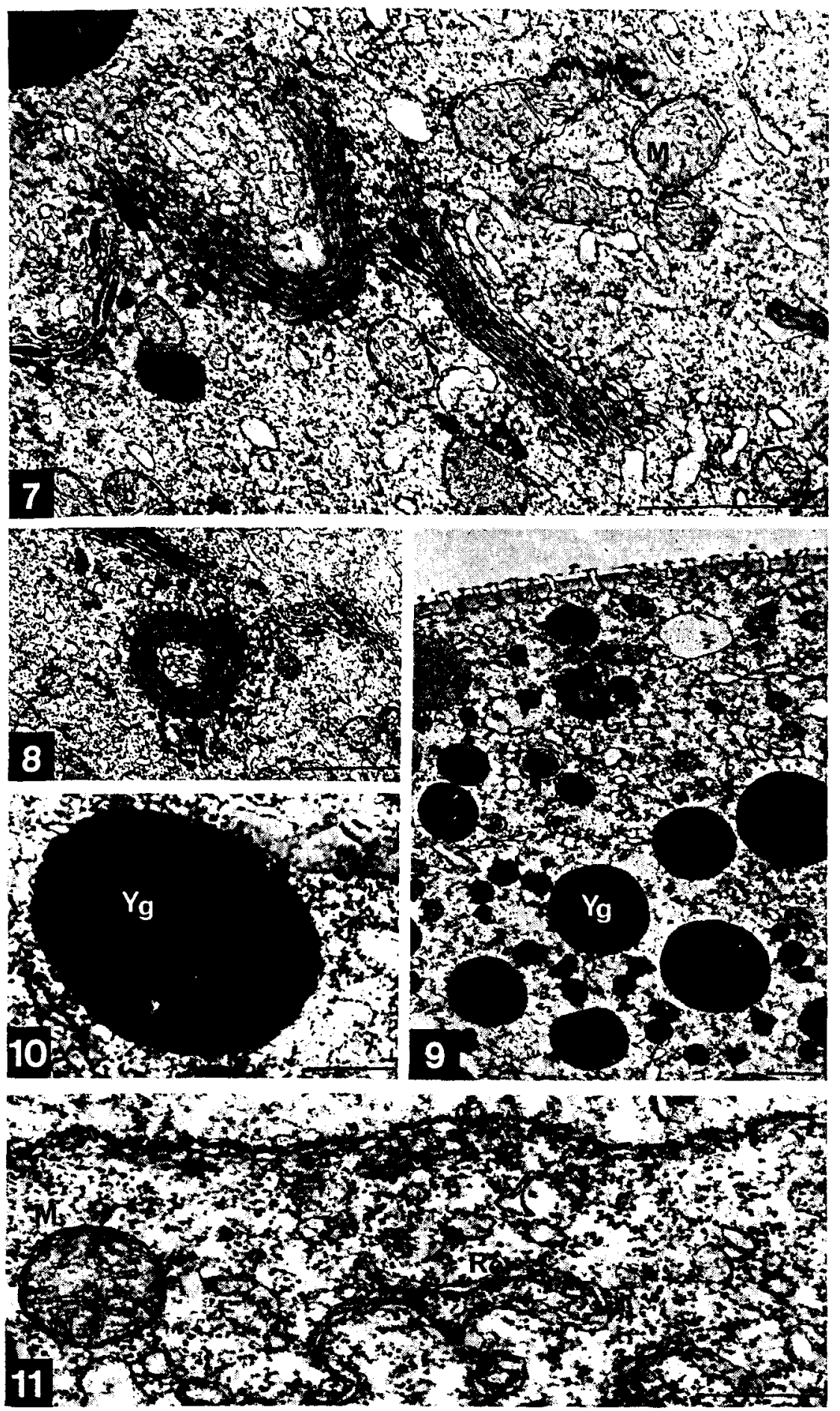
oocytes mature, the ovary assumes a structure rather like a bunch of grapes, in which oocytes are attached to the follicle cell network by stalks.

The surface of the early vitellogenic oocytes consists of simple bulbous microvilli (Fig. 17) $0.5 \mu \mathrm{m}$ high and about $0.2 \mu \mathrm{m}$ across the tips which protrude through the vitelline envelope. The vitelline envelope is an electron-dense layer outside the oolemma. It has a bi-laminar structure about $0.27 \mu \mathrm{m}$ thick with a thick inner layer and a thin, more electron-dense outer layer. Microvilli in late vitellogenic oocytes have stellate tips (Figs 18, 19). The development and the structure of the surface of the oocyte and its relationship to the follicle cells has implications regarding the hormonal support of oogenesis (Olive \& Bentley, 1980), since the completion of a microvillous surface must be attained before the oocytes are hormone independent and can be ovulated and spawned.

\section{Post-spawning resorption of unspawned oocytes}

Oosorption has been reported following incomplete spawning or spawning failure in a number of polychaetes including Nephtys hombergi (Olive et al., 1981a, b) where it seems to play an important role in the co-ordination of the reproductive cycle. Premature oosorption in $N$. hombergi occurs following gonadotrophic hormone deprivation during the vitellogenic phase. The ultrastructural changes which occur in the ovary and oocytes following this hormone deprivation have been described in detail (Olive \& Bentley, 1980). The ultrastructure of ovaries in which natural oosorption is taking place is essentially the same as that of ovaries in which oosorption has been experimentally induced by decerebration (hormone deprivation) and so will not be described here.

\section{DISCUSSION}

Oogenesis in Nephtys hombergi is of an ovarian type in which the oocytes are retained in ovaries by a simple follicle cell system. This kind of oogenesis could be regarded as of a type intermediate between solitary [or extraovarian (Eckelbarger, 1984)] oogenesis, in which oocytes are ovulated prior to the commencement of vitellogenesis, and follicular [or intraovarian, (Eckelbarger, 1984)] oogenesis where nutrients may be supplied to the developing oocytes by the follicle cells or from the genital blood vessel. The ultrastructure of solitary oogenesis has been described in a number of polychaete

Fig. 12. Electron-lucent cortical vesicles and electron-dense cortical granules near the periphery of a vitellogenic oocyte. Scale bar $=1 \mu \mathrm{m} .(\mathrm{Cg}=$ cortical granule, $\mathrm{Cv}=$ cortical vesicle $)$

Fig. 13. A large body of annulate lamellae in the cytoplasm of a vitellogenic oocyte. The presence of these is characteristic of oocytes in late vitellogenesis. Scale bar $=1 \mu \mathrm{m}(\mathrm{Al}=$ annulate lamellae)

Fig. 14. Clear vesicles associated with a body of annulate lamellae. These vesicles may represent expanded cisternae of rough endoplasmic reticulum. Scale bar $=1 \mu \mathrm{m}(\mathrm{A} 1=$ annulate lamellae, $\mathrm{V}=$ vesicle)

Fig. 15. Part of an oocyte which has completed vitellogenesis. It has large numbers of cortical granules at the surface and characteristic hollow mitochondria. Scale bar $=1 \mu \mathrm{m}$ (Cg $=$ cortical granule, $\mathrm{M}=$ mitochondrion) 

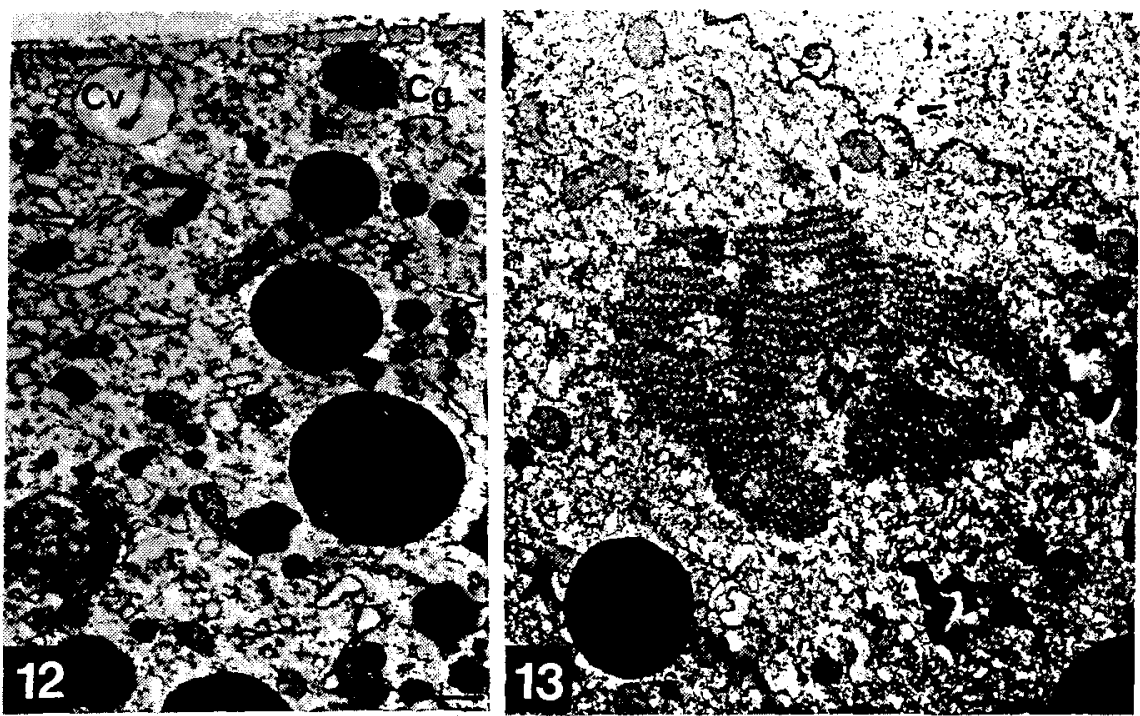

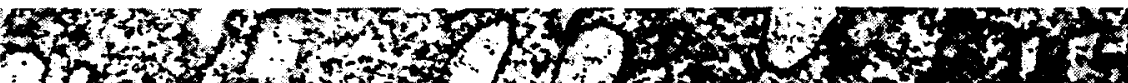

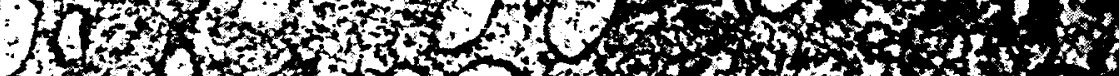

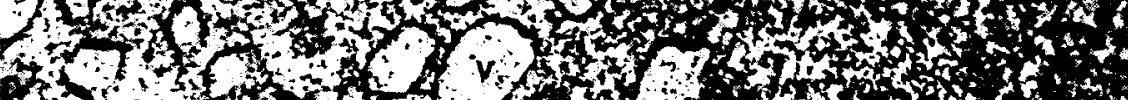

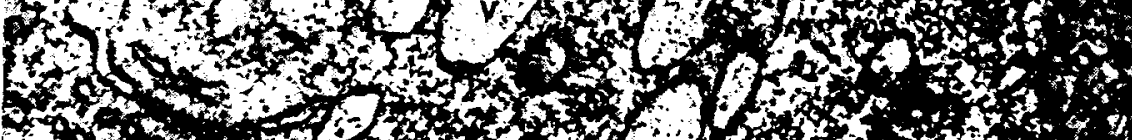

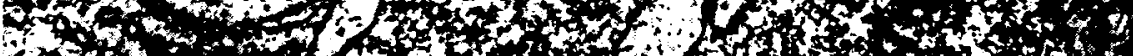

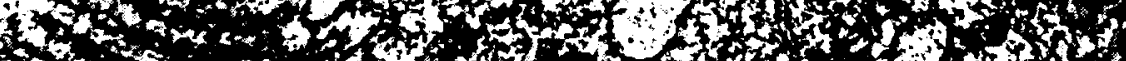

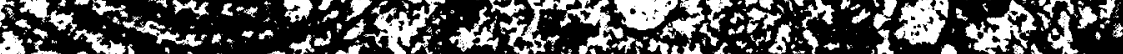

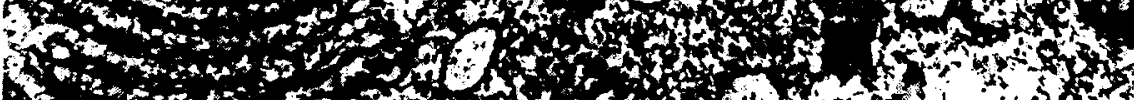

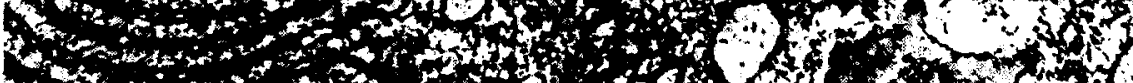

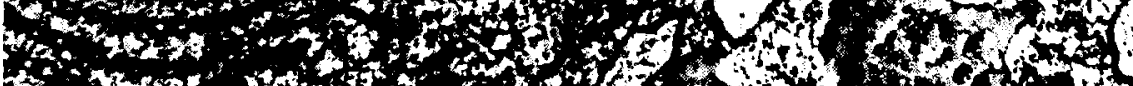

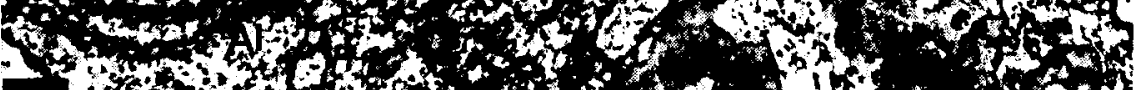

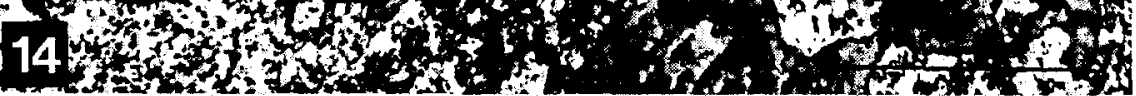

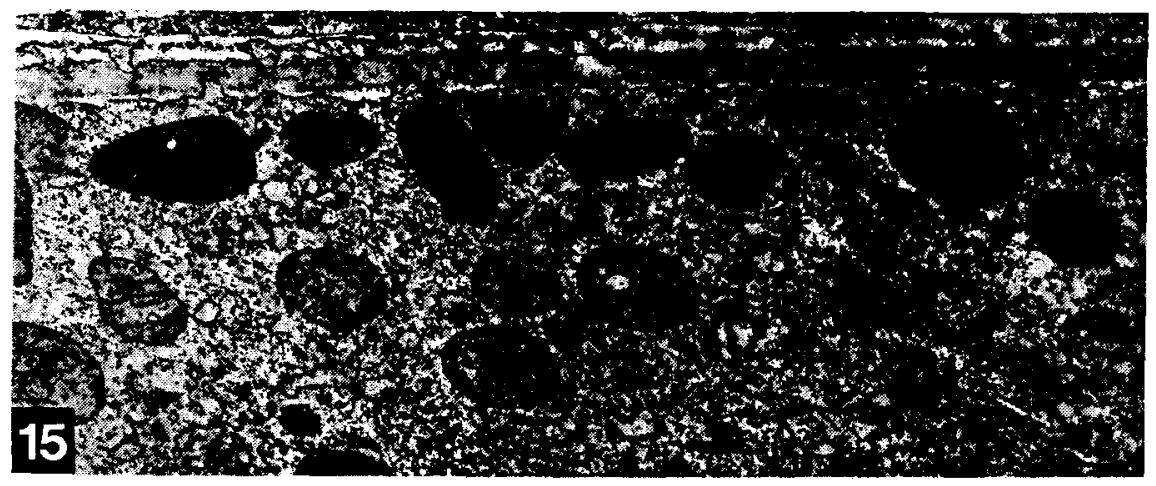


species including Nereis diversicolor (Dhainaut, 1967, 1969a, b), Nereis pelagica (Dhainaut, 1970; Dhainaut \& Porchet, 1977a, b), Nereis virens (Fischer \& Dhainaut, 1985), Platynereis dumerilii (Fischer, 1975), and Arenicola marina (Rashan \& Howie, 1982). In some cases, such as in Platynereis dumerilii (Fischer, 1975), there may be intimate contact of early oocyte stages with the follicle cells. These appear to play no part in the supply of nutrients to the developing oocytes but rather have a mechanical, supportive role (see Olive, $1983_{i}$ Eckelbarger, 1984 for review). Intraovarian oogenesis may involve nutritive support for the oocyte from follicle cells or from the genital blood vessel, or the follicle cell system may simply serve to contain the oocytes throughout vitellogenesis. In Phragmatopoma lapidosa (Eckelbarger, 1979) and Streblospio benedicti (Eckelbarger, 1980) complex contacts between oocytes and genital blood vessels are maintained throughout oogenesis, and endocytotic profiles (coated pits) provide evidence that the oocytes obtain part of their protein yolk material (a heterosynthetic component) directly from the blood vessels. In a number of other polychaetes whose ultrastructure has been described such as Kefersteinia cirrata (Olive \& Pillai, 1983) and Harmothoe imbricata (Garwood, 1981) and in Nephtys hombergi, reported here, oocytes are retained within the ovaries throughout vitellogenesis and whilst complex contacts between follicle cells, blood vessels and oocytes may exist at the previtellogenic stage, these contacts are lost as vitellogenesis proceeds and there is no ultrastructural evidence to suggest any heterosynthetic yolk synthesis. The simple follicle cell system which exists in Nephtys hombergi during vitellogenesis maintains the integrity of the ovary by simple contacts between the oolemma and follicle cell membrane. It has been established that a gonadotrophic hormone maintains these contacts until the oocytes have completed the formation of a microvillous surface (Olive \& Bentley, 1980). The cytology of the developing oocytes in $N$. hombergi is typical of oocytes which are believed to have autosynthetic yolk production. There is the presence of large numbers of mitochondria, rough endoplasmic reticulum and active golgi profiles producing material which condenses to form yolk granules. Annulate lamellae are also present but although they are commonly observed in oocytes their precise function remains unknown (see Eckelbarger, 1984). Whilst there may be no ultrastructural evidence to suggest that heterosynthetic yolk formation occurs (coated pits at the surface of the oocyte or synthetic apparatus within the follicle cells) this cannot be ruled out and biochemical studies would be required to establish this. The use of radiolabelled precursors as probes for the investigation of oocyte yolk synthetic pathways have now been carried out, in conjunction with electron microscopy, in a number of polychaete species, most notably in the Nereidae. The identification of a high molecular weight yolk protein precursor "Nereis vitellin" in Nereis virens (Fischer, 1979; Fischer \& Schmitz, 1981; Fischer et al., 1984) and Perinereis cultrifera (Baert, 1985, 1986a, b) has enabled the heterosynthetic pathway and incorporation into the oocyte of one type of yolk protein to be demonstrated (Fischer et al., 1984; Fischer \& Dhainaut, 1985). A second, autosynthetic pathway of yolk protein formation has also been demonstrated in the Nereidae by the uptake of radio-labelled amino acids (and sugars for the synthesis of complex polysaccharides) (Dhainaut, 1967, 1969, 1970; Dhainaut \& Porchet, 1977a, 1977b; Dhainaut, 1984). An investigation into the biochemistry of yolk synthesis in Nephtys would clearly tell us a great deal, especially in the light of the information we have available on the gonadotrophic hormone in this species (Olive \& Bentley, 1980; Bentley, 1982; Bentley \& Olive, 1982). 


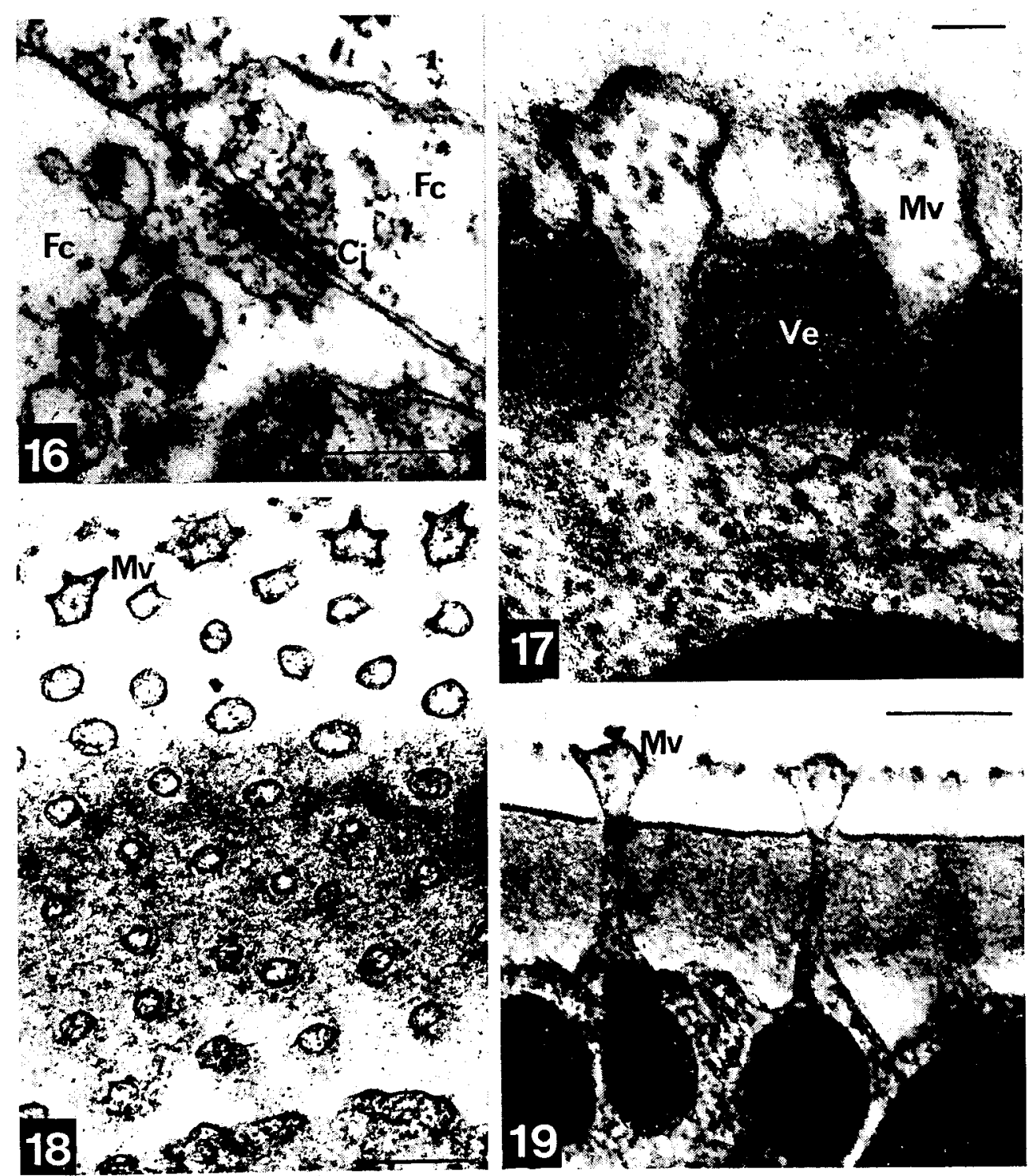

Fig. 16. A complex junction between two adjacent follicle cells. These junctions do not occur between oocytes and follicle cells. Scale bar $=0.5 \mu \mathrm{m}$

Fig. 17. Bulbous microvilli of an early vitellogenic oocyte. Scale bar $=0.1 \mu \mathrm{m}$

Fig. 18. A tangential section through the surface of a late vitellogenic oocyte. The microvilli at this stage have narrow stalks and hexagonal tips. Scale bar $=0.5 \mu \mathrm{m}$

Fig. 19. The microvilli of a late vitellogenic oocyte have narrow stalks and spiky tips. Scale bar $=0.5$ 
Acknowledgements. Part of this work was carried out in the Department of Zoology, University of Newcastle upon Tyne under SERC grant GR/B/99583 to P. J. W. Olive. The author is grateful to Dr. P. J. W. Olive for commenting on the manuscript and to R. McD. Hewit for technical advice.

\section{LITERATURE CITED}

Baert, J.-L., 1985. Multiple forms of vitellin in young oocytes of Perinereis cultrifera (polychaete annelid): occurrence and relation to vitellin maturation in the oocyte. - Comp. Biochem. Physiol. $81 B, 851-856$.

Baert, J.-L., 1986a. Evidence for vitellin maturation within the oocytes of Perinereis cultrifera (polychaete annelid). - Comp. Biochem. Physiol, 83B, 827-853.

Baert, J.-L., 1986b. Vitellin and vitellogenesis in the polychaete Perinereis cultrifera. In: Advances in invertebrate reproduction. Ed. by M. Porchet, J.-C. Andries \& A. Dhainaut. Elsevier, Amsterdam. 4, $207-214$.

Bentley, M. G., 1982. Gonadotrophic hormone in the Polychaetes Nephtys hombergi and N. caeca: an in vitro approach. - Gen. comp. Endocrinol. 46, 369.

Bentley, M. G. \& Olive, P. J. W., 1982. An in vitro assay for gonadotrophic hormone in the polychaete Nephtys hombergii Sav. (Nephtyidae). - Gen. comp. Endocrinol. 47, 467-484.

Bentley, M. G., Olive, P. J. W., Garwood, P. R. \& Wright, N. H., 1984. The spawning and spawning mechanism of Nephtys caeca (Fabricius, 1780) and Nephtys hombergi Savigny, 1818 (Annelida: Polychaeta). - Sarsia 69, 63-68.

Dhainaut, A., 1967. Étude de la vitellogenèse chez Nereis diversicolor O. F. Müller (Annélide: Polychète), par autoradiographie à haute résolution. - C. r. hebd. Séanc. Acad. Sci. Paris 165, $434-436$.

Dhainaut, A., 1969a. Étude ultrastructurale et cytochimique de la formation des inclusions intranucleaires dans les ovocytes de l'annélide Nereis diversicolor (O. F. Müller). - Z. Zellforsch. mikrosk. Anat. 96, 75-86.

Dhainaut, A., 1969b. Origine et structure des formations mucopolysaccharidiques de la zone corticale de l'ovocyte de Nereis diversicolor (O. F. Müller) (Annélide, Polychète). - J. Microsc. 8, $69-86$.

Dhainaut, A., 1970. Étude cytochimique et ultrastructurale de l'évolution ovocytaire de Nereis pelagica. I: Ovogenèse naturelle. - Z. Zellforsch. mikrosk. Anat. 104, 375-389.

Dhainaut, A., 1984. Oogenesis in polychaetes. Ultrastructural differentiation and metabolism of nereid oocytes. - Fortschr. Zool. 29, 183-205.

Dhainaut, A. \& Porchet, M., 1977 a. Évolution des constituants glucidiques de l'ovocyte de Perinereis cultrifera (Annélide: Polychète) dans les conditions naturelles. II. Étude autoradiographique des ovocytes jeunes. - Biol. cell. 28, 233-240.

Dhainaut, A. \& Porchet, M., 1977b. Evolution des constituants glucidiques de l'ovocyte de Perinereis cultrifera (Annélide: Polychète) dans les conditions naturelles. III. Etude autoradiographique des ovocytes submatures. - Biol. cell. 28, 241-250.

Eckelbarger, K. J., 1979. Ultrastructural evidence for both autosynthetic and heterosynthetic yolk formation in the oocytes of an annelid (Phragmatopoma lapidosa: Polychaeta). - Tissue Cell 11. $425-443$.

Eckelbarger, K. J., 1980. An ultrastructural study of oogenesis in Streblospio benedicti (Spionidae), with remarks on the diversity of vitellogenic mechanisms in Polychaeta. - Zoomorphology 94 , 241-263.

Eckelbarger, K. J., 1984. Comparative aspects of oogenesis in polychaetes. - Fortschr. Zool. 29, $123-148$.

Fischer, A., 1975. The structure of symplasmic early oocytes and their enveloping sheath cells in the polychaete, Platynereis dumerilii. - Cell Tiss. Res. 160, 327-343.

Fischer, A., 1979. A vitellin-like antigen in the coelomic fluid of maturing Nereis virens females. Naturwissenschaften $66,316-317$.

Fischer, A. \& Dhainaut, A., 1985. The origin of yolk in the oocytes of Nereis virens (Annelida: Polychaeta): Electron-microscopic and autoradiographic studies by use of unspecific and yolkspecific markers. - Cell Tiss. Res. 240, 67-76. 
Fischer, A. \& Schmitz, K., 1981. Preparation, properties and composition of Nereis vitellin, the yolk protein of the annelid Nereis virens. - Differentiation 9, 103-108.

Fischer, A., Buscher, L., Frangenberg, H.-R. \& Klenke, T. G., 1984. In vitro studies on the origin of yolk protein and its uptake by oocytes in the annelid, Nereis virens (Polychaeta). - Verh. dt. zool. Ges. 77, 145.

Garwood, P. R., 1981. Observations on the cytology of the developing female germ cell in the polychaete Harmothoe imbricata (L.). - Int. J. Invert. Reprod. 3, 333-345.

Millonig, G. J., 1961. Advantages of a phosphate buffer for $\mathrm{OsO}_{4}$ solutions in fixation. - J. appl. Phys. $32,1637$.

Olive, P. J. W., 1978. Reproduction and annual gametogenic cycle in Nephtys hombergii and $N$. caeca (Polychaeta: Nephtyidae). - Mar. Biol. 46, 83-90.

Olive, P. J. W., 1983. Annelida-Polychaeta. In: Reproductive biology of invertebrates. Ed. by K. G. \& R. G. Adiyodi. Wiley, London, 1, 357-421.

Olive, P. J. W. \& Bentley, M. G., 1980. Hormonal control of oogenesis, ovulation and spawning in the annual reproductive cycle of the polychaete Nephtys hombergi. - Int. J. Invert. Reprod. 2, 205-221.

Olive, P. J. W., Bentley, M. G., Wright, N. H. \& Morgan, P. J., 1985. Reproductive energetics, endocrinology and population dynamics of Nephtys caeca and Nephtys hombergi. - Mar. Biol. $88,235-246$.

Olive, P. J. W., Garwood, P. R. \& Bentley, M. G., 1981a. Oosorption and reproductive failure in Polychaeta in relation to their reproductive strategy, - Bull. Soc. zool. Fr. 106, 263-268.

Olive, P. J. W., Garwood, P. R., Bentley, M. G. \& Wright, N. H., 1981b. Reproductive success, relative abundance and population structure of two species of Nephtys in an estuarine beach. - Mar. Biol. 63, 189-196.

Olive, P. J. W. \& Pillai, G., 1983. Reproductive biology of the polychaete Kefersteinia cirrata Keferstein (Hesionidae). I. Ovary structure and oogenesis. - Int. J. Invert. Reprod. 6, 295-306.

Rashan, L. J. \& Howie, D. I. D., 1982. Vitellogenesis in the lugworm Arenicola marina L. I. Cytological and ultrastructural observations. - Int. J. Invert. Reprod. 5, 221-231. 